Apart from the theoretical conclusions which Darlington and La Cour arrive at, their method of analysis (which they amplyillustrate) will now enable us to investigate and to compare the effects of radiations of different wave-lengths ( $X$ - and gammarays, noutrons and alpharparticles), and that of different dosage-rates, all of which are of great importance in the development of radiotherapy. The misgiving has often been felt, and quite recently expressed in Nature by a physicist"? "that there is an uncertainty about the action of X-rays which is very tantalizing. Completè success appears to be so near and yet continues to elude us". We now have, if not success, at least the prospect of success. The experiments of Darlington and La Cour give not only a new impetus to the study of the biological effects of radiation, but also a new foundation.

1 Apolant, H., Deutsche Medizin Wochenschrift, 13, 454 (1904).

Koernicke, M., Ber. Dtsch. Bot. Ges., 23, 404 (1905).

3 Strangeways, T. S. H., and Oakley, H. E. H., Proc. Roy. Soc., B, 95, 373 (1923).

- Strangeways, T. S. H., and Hopwood, F. L., Proc. Roy. Soc., B, $100,283(1926)$.

'Mayneord, W. V., 'Whe Physics of X-Ray Therapy"' (London, 1929).

- Colwell, $H$. A., and Russ, S., "Radium and $X$-Rays on Living Cells", 2nd edit. (London, 1924).

' Packard, C., Radiology, 25, 223 (1935).

- Langendorff, H., and Langendorff, M., Strahlentherapy, 40, 97 (1931).

Scott, C. M., Med. Res. Counc. Spec. Res. Ser., No. 223 (1937).

${ }^{10}$ Tansley, K., Spear, F. G., and Glücksmann, A., Brit. J. Ophthalmology, 21, 273 (1937).

${ }^{11}$ Muller, H. J., Science, 66, 84 (1927).

12 Stern, C., Natur u. Mus., 59, 577 (1929).

18 Muller, H. J., Reun. int. Phys. Chim. Biol., 8, 477 (1937).

14 Timoféeff-Ressovsky, N. W., "Experimentelle Mutationsfonschung in der Vererbungslehre" (Dresden, 1937).

15 Fricke, H., and Demerec, M., Proc. Nat. Acad. Sci. Wash., 23, 320 (1937).

10 Bauer, H., Demerec, M., and Kaufmann, B. P., Genetics, 28, 610 (1938).

17 Sax, K., Genetics, 23, 494 (1938).

${ }^{18}$ Catcheside, D. G., Biol. Re ., 20, 14 (1945)

19 Stadler, L. J., Proc. VIth Int. Congr. Genet. 274 (1932).

${ }^{20}$ Mather, K., and Stone, I. H. A., J. Genet., 28, 1 (1933).

1 Koller, P. C., Proc. Roy. Soc. Edin., Sect. B, 61, 398 (1943).

2 Darlington, C. D., and La Cour, L. F., J. Genet., 46, 180 (1945).

s Darlington, C. D., and Upcott, M. B., J. Genet., 41, 297 (1941).

24 Koller, P. C. (unpublished data).

${ }^{85}$ Mitchell, J. S., Nature, 146, 272 (1940)

" Koller, P. C., Nature, 151, 244 (1943).

7 Crowther. J. A., Nature, 155, 351 (1945)

\section{THE BELGIAN NATIONAL FUND FOR SCIENTIFIC RESEARCH}

\author{
By JEA.N WILLEMS, C.B.E. \\ Director of the National Fund for Scientific Research
}

$\mathrm{O}_{0}^{\mathrm{N}}$ October 1, 1927, King Albert spoke on the occasion of the 110th anniversary of the creation of the Cockerill Works at Seraing, at the very centre of the industrial district of Liège. "Nations," he declared, "which neglect seience and scientific men are marked for decadence. Considerable and sustained efforts must be made; there must be more initiative if we wish - as we must wish-to maintain our position and our reputation. To-day, those who do not go forwards go backwarde."

This speech was made less than ten years after the conclusion of the War of 1914-18, when the "Fondation Universitaire", as well as the funds of the various Belgian universities, had been richly endowed, following the winding up of the Commission for Relief in Belgium and of its Belgian counterpart, the "Comité National de Socours et d'Alimentation".
It emphasizes the pressing demands made by science and the continual expenditure which has to be faceo for the maintenance of intellectual standards. King Albert's urgent appeal received a generous response and three months later public subscription had provided Belgium with 115,000,000 francs. This led to the creation, on April 27, 1928, of the "Nationa] Fund for Scientific Research", which aimed at intensi. fying scientific activities, and at placing research workers and scientific men in such a position that they could play a worthy part in the moral and material development of the country.

The new institution benefited immediately from the active co-operation of the most eminent representatives of the academic world. Its programme of activities included all questions which had necessitated and justified its creation, and it soon appeared that the measures adopted justified the highest hopes. At first, however, the National Fund was scarcely known outside Belgium. It suddenly came to general notice when it assumed responsibility for a perilous venture which was eagerly followed all over the world. This was the first stratospheric ascent by Prof. Piccard. Within three days, this man of science achieved popular renown. Homage was paid to him at a scientific meeting, when Prof. Bordet, himself a Nobel prizewinner, said: "Your exploit, which has thrilled men of science, has gone straight to the heart of the people. They are filled with admiration when they see a man of your intellectual power champion the cause of science with the courage of a hero."

The National Fund was applauded for its share in this work, which proved its desire to promote actively international science.

This favourable impression was confirmed by the archæological excavations pursued at Apamea. One of the immense porticos which stood above the high. way of this wealthy Syrian city, once a rival of Antioch, was partially reconstructed. Apamea was plundered and burned by the Persians in the seventh century B.C.; but the discoveries made among its ruins have revealed original works of art and archi. tecture, and particularly wonderful mosaics. These remains, now in the museums of Brussels, enable us to recapture some of the features of the ancient Persian and Roman town. The names of three Belgian historians and archæologists, Henri Pirenne, Franz Cumont and Fernand Mayence, are associated in this fine work.

Equally valuable results of another expedition sup. ported by the National Fund are also gathered together in the Brussels Museums of Art and History. This expedition went to Easter Island, in the Pacific Ocean, and investigated the enormous statues carved in the rock, reaching heights of $6-30 \mathrm{ft}$., and weighing up to 40 tons. A Franco-Belgian mission, including M. Henri Lavachery, now keeper of the Royal Museums of Art and History, undertook the journey and succeeded in gathering valuable information on a most interesting problem. This was to discover whether the writing known by the natives of the island in the fourteenth or fifteenth century could be identified with that shown on slabs discovered in India, and dating as far back as 2,500 B.c. From this it was hoped to ascertain whether Easter Island was the remainder of a lost continent and of a rich civilization since vanished.

Another expedition sponsored by the National Fund was equally successful. Ruwenzori had first been seen by Stanley in 1888, and since then its eastern 
slope had been explored several times, the highest summits having been climbed for the first time in 1906 by the Duke of Abruzzi. But the western slope had remained unexplored. This part of the mountain lies within the boundary of the Belgian Congo, and the Belgian mission undertook to study methodically its geology, flora and fauna. Thanks to their skill and endurance, the expedition gathered much information, and hoisted the Belgian flag at an altitude of $15,000 \mathrm{ft}$.

About the same time other men tackled, with great devotion, a problem which combined scientific and humanitarian interests. For a long time, Belgian missionaries had pursued their work in certain parts of China. One of them, the Rev. Father Rutten, returned to that country accompanied by two medical men, and undertook long journeys to vaccinate missionaries. Their aim was first to check, in endemic conditions, the preventive methods advocated by Dr. Weigl, the Polish man of science, and secondly to test the curative value of a serum in cases of exanthematic typhus. The results obtained are well known: whereas in former years the Belgian community of Scheut lost a number of missionaries, no case of disease was recorded after vaccination, but the same mortality prevailed in the missions where vaccination had not taken place. These results were published by the French bacteriologist, Charles Nicolle, and by Prof. Bruynoghe, of the University of Louvain.

Belgium also took part in the organization of the International Polar Year (1932-33). Ever since 188283 the idea had been mooted of active co-operation of scientific workers belonging to various countries in order to bring more unity and co-ordination into the work of polar expeditions. The programme of the second Polar Year, prepared a long time ahead in the course of international conferences, included a great number of subjects: the meteorology and explorations of the atmosphere; the dynamics of cyclones and anti-cyclones; weather forecasts; terrestrial magnetism and atmospheric electricity; earth currents and the aurora polaris.

Under the auspices of the Government and of the National Fund, Belgium undertook to establish a new magnetic station in the province of Liège and another in the Belgian Congo. These stations carried on observations, following the plans elaborated by the Polar Year Commission. The president, Prof. La Cour, director of the Copenhagen Observatory, paid tribute on several occasions to the part played by Belgian scientific workers in the common effort.

A few other examples of the activities of the National Fund can only be mentioned : participation in the new scientific station established on the Jungfraujoch; in the work of the Commission of New Analytical Reactions and Reactives, created by the International Union of Chemistry; in the works of the International Office for the Protection of Nature.

Then came the War and the German occupation. The country was separated from the civilized world and endured with great courage and devotion the oppression and sufferings of this eruel ordeal. Her mon of science and research workers resisted to the end. When one university was closed by the occupy. ing Power, other universities and institutions received its professors and students. When one institution lacked some product or apparatus, other institutions gave them or lent them. When some professors or academic authorities were arrested or dismissed, their colleagues filled the gap. Without publicity, the National Fund applied itself to the task of helping promising young men of science and research workers, and of solving questions arising from war conditions, such as the scarcity of food, and the protection of the unique stained glass windows of the Church of St. Gudule in Brussels. It has also prepared the ground for attacking post-war problems, within the framework of its traditions. All this necessitated inroads on available resources, and great tenacity in spite of unfavourable and often hostile surroundings.

To-day Belgian scientific workers are once more free to speak and act according to their scientific conscience. Contacts have already been established with their foreign colleagues, publications have been exchanged, and visits abroad are being planned. The joy derived from this release can only be appre. ciated by those who have for years been 'in prison' in an occupied country. We are beginning to hear of the eminent part played by men of science during the War. They will work to-morrow with the same zeal to further the material and moral reconstruction of the world. The National Fund for Scientific Research will continue to support Belgium in the part she is going to play in this great work.

\section{OBITUARIES}

The Right Hon. the Earl of Onslow, P.C., G.B.E.

LoRD ONsLow died, after a long illness, on June 9 last. He was a man of many parts, many corresponding activities and many friends, who were attracted to him by his own native friendliness and the affectionate simplicity and sincerity of his disposition. His many public services, in the course of which he left his mark especially on the day-to-day administration of local government, are a matter of record. He rendered other services which are, perhaps, less widely recognized, though, regarded in their true perspective and in the light of the fruit they may be expected to bear hereafter, they may prove to be the most important of them all.

A sportsman, and, like most of that fraternity, a field-naturalist, Lord Onslow became, as a matter of course, a fellow of the Zoological Society, and, after many years of useful service on the Council, was elected president in 1936 as the obvious successor to the late Duke of Bedford. To this new task he brought the high sense of duty and the unflinching industry which characterized all his undertakings. $\mathrm{He}$ had, already, in 1926, been chosen as president of the Society for the Preservation of the Fauna of the Empire. In this post he was in his element, and it was here that he did what may well prove to have been the most enduring and most valuable work of all. To him the preservation of wild life moant the preservation of the beautiful and interesting things the contemplation of which above all makes human life worth living. He recognized as few others did that man, "a little lower than the angels", was also only a little higher than the rest of the world ecology of which he is a part, and incomplete if divorced from that ecology. Further, he recognized that, though man could destroy, and was, on balance, a destructive rather than a productive animal, he could not create. If man destroyed a species, it was lost for ever, and man might discover too late that he had done himself irremediable harm; and whether 